\title{
Macrothink \\ Predictors of Ghanaian Language Students Choice of Programme: The Case of University of Education, Winneba
}

\author{
Jonathan Kweku Dodoo (Corresponding author) \\ University of Education, Winneba \\ E-mail: jkdodooiede@gmail.com \\ Dominic Kwaku Danso Mensah \\ Institute of Teacher Education \& \\ Continuing Professional Development (UEW), Ghana \\ E-mail: dominicdanso@yahoo.com
}

\author{
Dandy George Dampson \\ Department of Psychology and Education \\ University of Education, Winneba, Ghana \\ E-mail: dgdampson@gmail.com
}

Received: May 4, 2018 Accepted: May 20, 2018 Published: June 5, 2018

doi:10.5296/ijld.v8i2.13252 URL: https://doi.org/10.5296/ijld.v8i2.13252

\begin{abstract}
The main purpose of the study was to investigate the factors that are most influential in students' enrolment in Ghanaian languages programme in the University of Education, Winneba. The study employed the mixed sequential explanatory design. A total of 200 first year Ghanaian Language students of 2016/2017 Academic Year and staff members of the University of Education, Winneba-Ajumako Campus students were chosen through stratified proportional sampling technique to obtain the quantitative results. The Dean and admission officer of the Faculty of Ghanaian Languages and 12 students were purposely sampled and interviewed for the qualitative data. Frequencies, percentages and Independent sample t-test
\end{abstract}


were used to analyze the quantitative data whilst the qualitative data was analysed thematically. The findings of the study revealed that institutional reputation, course entry requirement, fee affordability and subject enhancing employability were considered very important factors in choosing Ghanaian language programme in UEW. The study found significant difference between the direct and mature students on course entry requirement, affordable fees and teachers as factors that affect their enrolment. It was recommended university authorities, faculty and administrative staff should ensure the reputation of the university as an institution for excellence is maintained by offering all stakeholders timely information on programme benefits, course entry requirement and fees schedules, financial aids and fee-payment policies.

Keywords: Student enrolment, programme choice, employability Ghanaian language

\section{Introduction}

There has been a significant increase in the numbers and variety of degree programmes being offered at the undergraduate level in most universities in Ghana. In 2013/2014 academic year enrolment into universities in Ghana rose by 7.1 per cent (President of Ghana, State of Nation Address-February 26, 2015). Even though the enrolment rate is rising, statistics suggest that it is not occurring equally among all programmes of study in the universities in Ghana (UEW Basic Statistics Report, 2015). Data gathered seems to suggest that enrolment into Ghanaian Language programme continued to experience a checkered goals failing to reach enrolment goals.

Table 1. Enrolment in Ghanaian Languages programme 2010-201

\begin{tabular}{llllll}
\hline Programme & $\mathbf{2 0 1 0 / 1 1}$ & $\mathbf{2 0 1 1 / 1 2}$ & $\mathbf{2 0 1 2 / 1 3}$ & $\mathbf{2 0 1 3 / 1 4}$ & $\mathbf{2 0 1 4 / 1 5}$ \\
\hline B.A Ga Education & 17 & 12 & 12 & 10 & 7 \\
B.A Dangme Education & 22 & 26 & 16 & 6 & 18 \\
B.A Dagaare Education & 7 & 8 & 8 & 6 & 11 \\
B.A Gonja Education & 3 & 10 & 10 & 10 & 12 \\
B.A Gurune Education & 46 & 44 & 44 & 20 & 61 \\
B.A Kasem Education & 10 & 5 & 2 & 8 & 7 \\
B.A Ewe Education & 56 & 57 & 2 & 8 & 44 \\
B.A. Nzema Education & 18 & 11 & 2 & 5 & 5 \\
B.A. Twi Education & 102 & 97 & 82 & 88 & 132 \\
B.A. Fante Education & 32 & 40 & 14 & 19 & 28 \\
\hline
\end{tabular}

Source: UEW Basic Statistics (2010, 2011, 2012, 2013, 2014).

Studies have shown that various factors inform students' decision to enrol on a programme of study. For instance, in Finland, Antti (2016) found that programme reputation and availability 
of tuition free education are factors that influence students' choice of a programme in the University of Oulu. In Spain, Sanchez (2012) established from his study that reputation and excellence, programme quality and access to direct and experiential sources of information and programme of study were factors that influenced students' choice of a programme. South Africa, Wiese, Van Heerden and Jordaan (2010) found that the single most important factor that determines students' choice of a programme of study at a higher institution was the quality of teaching at the quality of teaching. In Ghana, Owusu-Agyemang (2016) argued that individual demands, state and institutional policy objectives and industry-driven demands rather than demographic factors determine adult learners' participation in higher education. It, however, appears that little or no empirical have been conducted using students who have enrolled into Ghanaian language programmes in the University of Education, Winneba. It is against this background that the researchers sought to conduct this study.

\section{The Problem}

Enrolment into Ghanaian language programmes of study continues to experience a checkered process, failing to reach enrolment target. The low enrolment figures pose threat to university profile in terms of world universities ranking and programme image. Additional threats include dwindling of finances from students in terms of payment of tuition and other academic user fees. It also affects the general turnout for pre-tertiary institutions.

Despite numerous interventions put in place to bring about effective rigorous enrolment drive, there appears to be some more potent enrolment drive that may not be available to the University of Education, Winneba toward the choice to select courses especially to the Ghanaian Language programme. It is, therefore, imperative to conduct a scientific research into this problem to ascertain the important factors influencing choice of university programme and understand the distinction between direct entry students and mature students on these factors. The following research questions guided our study:

1) What factors mostly influence students to enrol in the Ghanaian Language programme in University of Education, Winneba?

2)Are there significant differences between direct entry and mature entry students on the identified factors that influence students to enrol in Ghanaian language programme in UEW?

\section{Theoretical Framework: Chapman's Model of Students' College Choice}

This study adapted Chapman's Model of Students' College Choice as the theoretical basis. Chapman's model implied that students decision to enrol in the university to pursue any programme of study are influenced by series of factors and these factors are students' background and external factors (Chapman,1981). Chapman (1981) defined students' background to include socio-economic status and high school performances. He asserted that the external influences include the influence of significant individuals, institutional fixed characteristics and institutional communication efforts to prospective students. Chapman (1981) asserted that a combined effect of the factors identified assists students in their choice of university to enrol to further their education pursuit. The empirical studies that were 
revealed were based on the four clusters of influencers namely academic programme, institutional factors, personal factors, and significant individual's factors in Chapman's model. These factors are discussed below:

\section{Academic Programme Suitability Factors that Influence Students Choice of a Programme}

\subsection{Employability of the Programme}

Studies have shown that the employment opportunities and job placement rates, improved job skills, better job, better paid occupation, better choice of a job internship opportunities, and industry partnerships are very important in decision to enrol career wise (Heslop \& Nadeau, 2010; Brewer \& Zhao, 2010). As students think of the kind of degree to obtain, they consider the usefulness of that certificate in the outside world (Jackson, 1982). Ming (2010) reported that students make programme choices based on existing career opportunities because they are interested in outcomes.

\subsection{Course Entry Requirement}

Regardless of all other factors pertaining to the choice of a programme, they cannot be divorced from the fact that the intelligence and academic ability of a student will ultimately influence it (Owoyele \& Toboyo, 2008). There are grade requirements for every academic programme and a student cannot enrol in a programme he or she does not have the required grade requirement (James, G., \& McInnis, 1999). Berry (2004) adds that the subject combination needed for some programmes in Higher Education Institutions has a huge bearing on whether students can pursue them or not. Thus, students consider the admission requirements of a programme before they enrol.

In Kenya, Lugulu and Musoga (2013) found that students' degree programme decisions were guided by the university's entry requirement. The findings indicated that students' degree programme and university placement were assigned to them by the placement board of public universities in Kenya. Similarly, the admission requirement into, especially, public universities in Ghana is very competitive, and the University reserves the right to limit admissions to such programmes within the regulations operating in the country. Students' personal preferences may conflict with degree requirement.

\subsection{Interest in Academic Programmes}

The foremost consideration of prospective students of academic programme is their interest. It will be relatively futile to enrol in a teacher education programme when one wants to be a doctor or an engineer. Kerin, Harvey and Crendell (1975), indicated that personal interest for programme is a very important attributes to students choice of programme for further studies. Kerin, Harvey and Crendell (1975), reviewed students interest for programme of study across three areas; intent to enrol based on perceived difficulty and relevance (b) factors influencing course selections and (c) the importance of programme information received. The perceived relevancy of the programme played a major part in the participate intent to enrol, as nine out of the twelve programmes received higher enrolment interest (Kerin et al., 1975). 


\subsection{The Reputation of the Institution on Choice of Programme}

Prior studies have identified that images of HEIs hosting the programme of study have powerful influence on future students' attitudes toward choosing a programme in many ways such as: university's competitiveness, accreditation, and brand name of the university (Kim \& Gasman, 2011; Pampaloni, 2010). There are extensive resources and opportunities accompanied with the fact that a student is studying in a certain university. The prestige of the university opens up so many doors for enriching internship, unique seminars, jobs and mentorship possibilities. The academic recognition an institution has, leads to students choice of a programme satisfaction. Poock and Love (2001) studied newly enrolled doctoral students from 24 institutions in the field of higher education administration. He found reputation of the institution and friendliness of the faculty were among the highest rated factors to students' choice of programme.

\subsection{The Quality of Teaching Staff}

Staff quality, the perception of teaching quality; the perception of education; learning and research methods, are all very important attributes for students to choose a programme in Higher Education institution (Kim \& Gasman, 2011; Maringe, 2006). In England particularly, studies find prospective students placing high premium on the reputation of the school based on the quality of their teaching staff (James, Baldwin, \& McInnis, 1999). On the other hand, Robinson and Bornholt (2007) find students in Australia expanding the set to include all staff.

\section{Significant Persons that Influence Choice of Programme}

Similar to evidence previously presented regarding to the factors that influence students choice of programme, significant people such as parents, teachers, friends ,alumni, academic counsellor have an influence on the students' choice process (Bick-Har, 2012). Lovelt (2007) identified friends and family to have a key influence on pre-service teachers' choice to enrol in teacher education in New Zealand.

In direct relation to the study of Ghanaian Languages programme and Ghana locality, Owie-Ewie and Edu-Buandoh (2004) carried a qualitative study and used semi-structured interviews and observations as data collection strategies to investigate the negative attitudes towards the study of Ghanaian language in the Senior High School (SHS). The study revealed that only students that are able to cope with the negative attitudes of the general public through self-motivation, encouragement from professors of Ghanaian language and Ghanaian languages teachers, alumni and interns from the University are able to further studies in Ghanaian language programme to the tertiary level.

Dewitte (2015) also conducted a study on indigenous languages and the academic implications for development in Kwame Nkrumah University of Science and Technology (KNUST) using the undergraduate students of Bachelor of Art in Akan as the target population. She found that ideological underpinnings, prestige, and discouragement from family and friends prevented students from pursuing the BA in Akan programme, but teachers' enroled in the Akan programme turned out to have positive language attitudes that 
can influence the language ideologies held by different actors in the educational system. To extend that research, this study sought to investigate the most important people that influence students to choose Ghanaian language programmes as a field of study in the university.

\section{Financial Issues that Influence Choice of Programme}

These factors have several aspects including; fees for study, value of fees, scholarship opportunities, other financial aids, material cost, fees for accommodation (including value of rent) and other living expenses as well as family budget (Wagner \& Fard, 2009; Beneke \& Human, 2010).

\section{Methods}

The study employed the explanatory sequential design as the researchers sought to use the qualitative data to help explain or build upon initial quantitative results (Creswell, Clark, Gutmann \& Hanson, 2003). The researchers first collected and analysed the quantitative data. This first phase was followed by the subsequent collection and analysis of the qualitative data. The second, qualitative phase of the study was designed so that it followed from (or connects to) the results of the first quantitative phase.

The College of Languages located at the Ajumako campus of University of Education, Winneba was chosen for the study. The College of Languages has two faculties; Faculty of Foreign Languages and Faculty of Ghanaian Languages. The Faculty of Foreign Languages was excluded from the study because the study focused on Ghanaian languages only. The Faculty of Ghanaian Language hosts twelve programmes namely Dagaare, Dagbani, Kasem, Gonja, Gurune, Kusaal, Ewe, Nzema, Twi, Fante Dangme and Ga programme (UEW Basic Statistics, 2016). All the programmes within the Faculty of Ghanaian Languages for the undergraduate programmes span a four-year duration, leading to the award of Bachelor's degree in Ghanaian Language Education (UEW Admission brochure, 2017). This site was chosen for the study based on the rationale that the College of Language of the University of Education, Winneba is the only University campus that uniquely runs intensive courses in the Ghanaian Languages programme in Ghana.

First year students who have enrolled on the Ghanaian language programme either as direct or mature students were the focus of this study based on the rational that continuing students might not be able to remember the factors that mostly influenced them to enrol in the Ghanaian language programme. Based on the accessible population of 620 registered undergraduate first year students for the 2016/2017 Academic Year in the Faculty of Ghanaian Language the appropriate sample size of 200 was calculated using Krejcie and Morgan (1970) formula of at least thirty percent (30\%) of the population for determining sample size. Since the study identified twelve different Ghanaian Languages being studied at the Faculty of Ghanaian Languages in UEW. In order to allow members of the population of course have equal opportunity of equal opportunity of being selected the researcher used stratified proportional sampling technique to get adequate representation of all programmes. With this proportional calculation, Ga Education had three (3), Nzema Education had five (5), Twi Education had forty seven (47), Dagaare had six (6),Dagbani had fifty three (53) Kasem Education had four (4), Kusaal Education had eleven (11), Gonja Education had 
nineteen (19) and Gurune had four (4). The researcher folded pieced of paper written "PART" in proportion to the number of students sampled from each course and on others "NOT PART" well mixed in a container. All those who picked the "PART" responses were made to complete copies of the questionnaire and those who picked "NOT PART" responses were excluded from the sample. For the second phase, purposive sampling technique was used to select the Dean of the Faculty of Ghanaian language, admission officer and one first year student from each of the twelve programmes for interview because of their answers in the quantitative phase.

The data collection methods employed was questionnaires and interviews. The Questionnaire was developed specifically to collect quantitative data. This helped identify the level of influence of the factors on choice of Ghanaian language programme. Interview was used to collect qualitative data for the second phase of the study. In this explanatory follow-up, the factors that mostly influence students' enrolment in Ghanaian languages programme were explored with students selected because of their answers in the quantitative phase plus the Dean of the Faculty of Ghanaian Languages and Admission officer. Descriptive statistics including mean and standard deviation were computed for each factor to establish those that mostly influence students' decision to enrol on the programme. A mean of 3.00 and above was considered very important. Inferential Statistics, specifically, Independent Sample t-test was computed to check the significance differences between the direct students and mature student on the identified factors that mostly influence students. The data from the interview was analysed into themes.

\section{Results and Discussions}

\subsection{Background Characteristics of Respondents}

The background information of the respondents which were considered included the gender and the admission status of the respondents. The majority of respondents were male $(59 \%)$, and the average age range was $25-29$ years, $50 \%$ of the total respondents of 200 . The majority $116(58 \%)$ gained mature admission whereas $84(42 \%)$ were direct students.

\subsection{Factors that Mostly Influence Students to Enrol in the Ghanaian Language Programme in University of Education, Winneba}

This section sought to establish the most influential factors that influenced the students' choice of the Ghanaian Language programme. The views of the students in reference to this research question is presented in Table 2. 
Table 2. Influential factors to students' choice to enrol in the Ghanaian Language programme

\begin{tabular}{llll}
\hline Influential factors & Mean & SD & Rank \\
\hline Reputation of institution & 4.10 & .860 & 1 \\
Course entry requirement & 4.08 & .935 & 2 \\
Subject enhancing employability & 3.49 & .839 & 3 \\
Affordable fees & 3.95 & 1.081 & 4 \\
Teachers & 3.69 & 1.320 & 5 \\
Alumni & 3.00 & 1.025 & 6 \\
Parents & 2.89 & 1.065 & 7 \\
Parental income & 2.86 & 1.045 & 8 \\
School counsellor & 2.69 & 1.150 & 10 \\
Quality of teaching staff & 2.59 & .738 & 11 \\
Study leave with pay & 2.41 & 1.013 & 12 \\
Scholarship availability & 2.16 & 1.100 & 13 \\
Friends or colleagues & 2.09 & 1.038 & 14 \\
Already teaching Ghanaian language as a subject in school & 1.87 & 1.026 & 16 \\
\hline Sarce Fidwork (2017). & & &
\end{tabular}

Source: Fieldwork (2017).

Data from Table 2 for the quantitative analysis, six variables were identified from the seventeen influencing factors as having the highest scores in the level as ranked with a 3.0 or above; namely the reputation of institution $(\mathrm{M}=4.10 ; \mathrm{SD}=.860)$. Students together with their relatives would always choose institutions of higher repute as these institutions may enhance their employability in the job market in addition to the skills that these institutions would impart on the students. Aside the reputation of the university as a whole, the reputation of the department also influenced the students' choice of the programme of study. For instance, one of the respondents remarked in the interview that:

I have always preferred to be in a training college therefore getting to know that students of the Ghanaian languages are treated in a similar way, I decided to pursue further studies therein love the school. The college is a family, it so easy to get connected to your lecturer (Interview data, Respondent \# 8).

Another respondent remarked:

Despite the general negative attitude portrayed by the society against the study of indigenous languages, the reputation of UEW's College of Languages seems to have a positive influence on enrolment in the study of Ghanaian languages at the tertiary level (Interview data, 
Respondent \# 1).

Another respondent corroborated this position by saying that:

I decided to enrol in University of Education, Winneba to pursue my studies because I learnt it is the only university offering Dagbani Education in Ghana (Interview data, Respondent \# $5)$.

The findings are in consonance with Alonderiene and Klimaviciene (2013), who asserted that the state of being accepted in a prestigious institution is one of the factors that influence students' choice of a programme of study. In this respect, Ghanaian language programmes are no different than any other programme or field of study. The findings also support the findings of Sabir, Ahmad, Ashraf and Ahmad (2013) that prominence from reputation of institution; press reviews; staff reputation; ranking and the website of the institutions influence students' choice of a programme of study. Kusumawati (2013) also asserts that the reputation of institutions influences students' choice in choosing an HEI.

Another factor that was identified to influence the students choice of the programme was Course entry requirement $(\mathrm{M}=4.08, \mathrm{~S}=.935)$. Students would always opt for programmes where they feel the meet the required entry behaviours. This is particularly true when the programme is quite competitive among graduates from the Senior High School. The interview with the Dean of the Faculty of Ghanaian Languages revealed that admission into the programme is based purely on merit. In view of this, students would always ensure that the meet the minimum entry requirement before they apply to the school. In the interview, the Dean revealed:

Admission into university is purely on merit. One has to satisfy both the minimum requirement for admission set by the national accreditation board as well as satisfying the departmental requirement of the programme of interest. The College has instituted a strategy to absorb all qualified applicants who could meet the first choice requirement but had good grades in any of the Ghanaian languages subject (Interview data, Respondent \# 3).

With regard to the students, one of them indicated that:

I have always enjoyed reading and teaching at Sunday school using the Twi Bible. I happened to be around to listen to a former student discuss the entry requirement of the university. I therefore decided to show my result to her, who then confirmed that I qualified to apply (Interview data, Respondent \# 7).

In addition, the quantitative results showed that subject enhancing employability $(\mathrm{M}=4.08$, $\mathrm{S}=.935$ ) influenced their choice of the Ghanaian language programmes. This is not surprising as students would always opt to study a programme at the university when information available to them points to the direction that jobs are readily available to them upon graduation. This was not different from the views of the respondents which they expressed in the interview. For instance, one student affirmed:

The choice of major is likely to be influenced by expectation of job availability. I must state on authority that, there are many of our alumni working as lawyers, journalist, bankers, 
lecturers, teachers and other reputable fields of work. I believe there are more career paths and jobs in the Ghanaian languages field of study (Interview data, Respondent \# 1).

It is also evident from the perspective of the student that the programme offers the opportunity for them to develop expertise in other content areas which would enhance their employability skills in the classroom as well as other fields of endeavour. One student who support this assertion intimated:

The availability of joint honour of degree in two subjects is of great joy to me. I am currently offering Twi and English language education. I would be able to develop content for other subjects. I learnt I can even further (Interview data, Respondent \# 6).

Another student postulated:

I intend to have further studies and more learning that would be helpful in my career and personal growth in the subject area to enhance for promotion at the work place (Interview data, Respondent \# 12).

Interestingly, the university's reputation is linked to subject enhancing employability prospects in the teaching field in Ghana. Many of the students interviewed raised the issue of their interest to teach Ghanaian languages at the pre-tertiary level. This means that the students view the programme as effective in ensuring that they are able to teach to meet the language demands of the society at all levels of education that precedes the university.

Affordability of fees $(\mathrm{M}=3.95, \mathrm{~S}=.1 .081)$ was also identified by the respondents as the fourth factor that influence their choice of their programme of study. The subsequent qualitative seems to suggest that students are not timely informed of fees and academic user fees. Most students make their decision based on previous fees. Some tend to abandon their admission when the fees variation is huge. Cost was ranked first among the top five by a study carried on Indonesian students' perception of choice criteria (Kusumawati, Yanamandram, \& Perera, 2010). When asked about the "Affordable Fees" on choice of Ghanaian language programme in University of Education, Winneba, about $80 \%$ of the students who were interviewed expressed that there was inadequate information as far as fees payment is concerned. For instance, one of the students who were interviewed said:

In order to make informed decisions one requires a great amount of information and engagement from a university. One has to make several calls to no avail concerning academic user fees. Our parents require timely information to incorporate in their financial planning toward our education (Interview data, Respondent \# 4).

In addition to the lack of information to students who are ready enrol on the programme, one of the students mentioned:

Access to quality information, advice and counselling is essential pre-requisite for mature students returning to university education for further studies in any field. There has been criticism that although there are services for those who are traditional or direct students, the provision of those who are mature learning has not been satisfactory at all (Interview data, Respondent \# 1). 
Despite the lack of responsiveness on the part of authorities in providing timely information regarding the financial requirements of the programme, the students maintained that they were influenced by the cheaper rate of the programme as compared to other programmes run by the institution and other institutions in Ghana. Again, it appears that the university offer other forms of assistance to the students. From the interview, one of the students said:

Ghanaian language programmes in UEW's fees are relatively cheaper compared to fees of institutions offering similar programmes. Aside the relatively moderate fees, there are several pools of financial aids that students can seek support from. These include the Vice Chancellor's scholarship for the brilliant but needy student, and government's Students Loan Trust Fund. However, there are no scholarships exclusively for the Ghanaian languages education (Interview data, Respondent \# 1).

Another student also posited:

Some of us are taking care of ourselves plus our families therefore fees affordability is of great importance to our decision of pursuing further education. Scholarships are not hundred percent guaranteed that one can necessarily add to his/her planning (Interview data, Respondent \# 6).

In response to how the fees students pay at UEW compares with that of other tertiary institutions in Ghana, one of the student said:

Surely, the cost of education in University of Education, Winneba is relatively cheaper than the private universities and some public universities offering similar programmes. My main concern has to do with constant delay in releasing the fees schedules (Interview data, Respondent \# 12).

The quantitative data further revealed that teachers $(M=3.69, \mathrm{~S}=.1 .316)$ and the Alumni $(\mathrm{M}=3.69, \mathrm{~S}=.1 .025)$ play critical roles in wooing students to enrol on the Ghanaian Languages Programme at the University of Education, Winneba. Further interrogations were made about the most influential persons to students' choice of Ghanaian Languages in UEW through the interview. From the interview, majority of the interviewees expressed their views on the role of teachers and alumni to their choice. For instance, one of the students revealed that:

Teachers and alumni are the main recruiters into university programmes. Parents rely heavily on them for authenticity of any information received about the university from other sources (Interview data, Respondent \# 1).

Another student affirmed that:

My admiration for my Ghanaian language SHS teacher pursued me to decide to enrol in Ghanaian language programme. The way she speaks and writes both English and Twi excellently built the interest in me (Interview data, Respondent \#12).

Another student also said:

Most alumni serve as a source of confirmation for most students. My Senior High School 
teacher was very instrumental for me enroling in UEW to pursue Twi education (Interview data, Respondent \# 2).

Another student also intimated:

My father teaches Ghanaian languages in SHS; he encouraged me to further studies in the same field (Interview data, Respondent \# 6).

Teachers are considered as role models in our society, their views are highly respected among their students. Most of the Ghanaian teachers in the senior schools, depending on the satisfactions they received from former institutions tend to be the main recruiters for the programme.

The least influential factors that were identified through the quantitative study included study leave with pay $(M=2.41 ; S D=1.31)$, Scholarship availability $(M=2.16 ; S D=1.100)$, Friends or colleagues $(M=2.09 ; S D=1.038)$ Friends or colleagues $(M=2.16 ; S D=1.100)$, and Already teaching Ghanaian language $(M=1.87 ; S D=1.026)$ factors with mean scores below 2.50 as presented in Table 2. A critical look at the evidence deduced from research question one revealed an in-depth picture of the most important factors that influence students' choice of Ghanaian languages Education in UEW. The findings revealed that there are multiple interrelated factors influencing students' choice to study Ghanaian languages. All the six very important factors were confirmed by the subsequent qualitative studies.

9.3 Differences Between Direct Entry and Mature Entry Students on the Identified Factors that Influence Students to Enrol in Ghanaian Language Programme in UEW

The intent of this research objective was to establish whether significant differences exist between direct entry and mature entry students on the identified factors that influence students to enrol in Ghanaian language programme in UEW. The results of the analysis is presented first. 
Table 3. Results of T-tests and descriptive statistics most influenced factors by nature of admission

\begin{tabular}{|c|c|c|c|c|c|c|c|c|}
\hline \multirow{3}{*}{ Outcome } & \multicolumn{4}{|c|}{ Group } & & & & \\
\hline & \multicolumn{2}{|c|}{ Direct $(N=84)$} & Mature & $(\mathrm{N}=116)$ & & & & \\
\hline & $\mathbf{M}$ & SD & $\mathbf{M}$ & SD & $\begin{array}{l}\text { 95\% CI for } \\
\text { Mean } \\
\text { Difference }\end{array}$ & $\mathbf{T}$ & Df & P value \\
\hline Reputation of institution & 4.01 & .871 & 4.16 & .851 & $.-386, .99$ & -1.16 & 166 & .246 \\
\hline Course entry requirement & 4.48 & .611 & 3.78 & 1.02 & $.445, .938$ & 5.53 & 162 & .000 \\
\hline Affordable fees & 3.30 & 1.05 & 4.41 & .835 & $-1.38,-853$ & -8.36 & 191 & .000 \\
\hline Teachers & 3.37 & 1.44 & 3.92 & 1.18 & -919,-..188 & -2.98 & 157 & .003 \\
\hline $\begin{array}{l}\text { Subject enhancing } \\
\text { employability }\end{array}$ & $\mathrm{g}_{3.52}$ & .911 & 3.47 & .785 & $.-179, \quad .2 .96$ & .484 & 150 & .629 \\
\hline Alumni & 2.85 & 1.09 & 3.10 & .964 & $.846, \quad .030$ & -1.76 & 165 & .079 \\
\hline
\end{tabular}

Source: Fieldwork data $(2017) * \mathrm{P}<0.05$.

Table 3 shows the results of the independent sample t-test on the differences between direct entry and mature entry students on the identified factors that influence students to enrol in Ghanaian language programme in UEW. The results of this test indicated that there were statistically significant differences in course entry requirement factors influencing choice of Ghanaian language programme between $\operatorname{direct}(\mathrm{M}=4.48, \mathrm{SD}=.611, \mathrm{n}=84)$ and mature $(\mathrm{M}$ $=3.78, \mathrm{SD}=1.02, \mathrm{n}=164)$ at the. 05 level of significance $(\mathrm{t}=5.53, \mathrm{df}=191, \mathrm{p}<.05,95 \%$ CI for mean difference. 445 to. 938). On average, direct entry students tend to be more influenced by the course entry requirement than the mature students. On the account given by respondents on influence of course entry, it was revealed that direct students tend to apply to many institutions with varied options. They, therefore, tend to give more attention to the entry requirements than the mature students who mostly apply to one institution and hope to meet the required marks for admission. From the interview, one of the direct students affirmed this by saying that

I applied only to university of education and was sure of securing Admissions after two attempts of writing mature entry examination (Interview data, Respondent \# 4).

Another direct student also said:

I applied to university of education to read Political Science but later I received a call from the university that I do not have the required subject combination to read political subjects 
but qualify to read Fante Education, haven scored aggregate B3 in Fante at the SHS level (Interview data, Respondent \# 7).

In direct confirmation to the findings, one matured student also indicated:

I intended to have further studies and more learning that would be helpful in my career and personal growth in the subject area to enhance for promotion at the work place; entry requirement was not an issue (Interview data, Respondent \# 6).

This shows clearly that as far as applying for a programme of study is concerned, the matured students cared less about the entry requirements unlike the direct students who were much interested in finding out whether the grades they obtained from the Senior High School commensurate with the demands of the institutions they were applying to. The result is line with those reported by Lugulu and Musage (2013) that students, degree programme decisions were guided by university entry requirement. Secondly studies by Reay (2002) and Shanahan (2000) revealed that mature students are motivated by career advancement, desire to improve qualifications, interest in the chosen subject, personal development or change of subject. It is obvious that course entry requirement is not one of the most important factors that influence mature students in their decision for higher education.

Similarly, the results of this test indicated that there were statistically significant differences in affordable fees as a factor influencing choice of Ghanaian language programme between direct $(\mathrm{M}=3.30, \mathrm{SD}=1.05, \mathrm{n}=84)$ and mature $(\mathrm{M}=4.41, \mathrm{SD}=.835, \mathrm{n}=164)$ students; $\mathrm{t}=$ $(5.97)=191, \mathrm{p}=.000$. These findings indicated that on average, mature students tend to be more influenced by affordable fees than direct students. This is quite expected given the fact that many families find it extremely hard to raise enough money to care for their wards. As a result, students would always apply to institutions where they can afford the fees. Again, the students are likely to choose programmes of study like teaching that are highly subsidize by the central government compared to programmes that are classified as fee paying. This is supported by the Chung and Yi-Cheng (2012) study that revealed that majority of students choose teaching profession due to extrinsic reasons including lower tuition fees, enhanced job opportunities and social stability.

Furthermore, the results of the test indicated that there were statistically significant differences in teachers factor influencing choice of Ghanaian language programme between direct $(\mathrm{M}=3.37, \mathrm{SD}=1.44, \mathrm{n}=84)$ and mature $(\mathrm{M}=3.92, \mathrm{SD}=1.18, \mathrm{n}=164)$ at the .05 level of significance $(\mathrm{t}=2.98, \mathrm{df}=191, \mathrm{p}<05,95 \% \mathrm{CI}$ for mean difference 919 to 1.88$)$.

However, with the results of the independent sample t-test for the most influential factors on direct and mature entry students shows that no statistical difference exists between them in terms of the reputation of institution, subject enhancing employability and Alumni influence. As shown in the table, the significance level of the independent sample t-test is 2.46, 629 and 079 for reputation of institution, subject enhancing employability and Alumni influence respectively is greater than the p.-value of 0.05 . There is no evidence that the mean difference is significant at a level of 0.05 .Therefore, we cannot conclude that the influence of reputation of institution, subject enhancing employability and alumni is different between direct and mature students in their choice of Ghanaian language as their major in the university. 


\section{Macrothink}

Overall, this analysis presents a positive picture of the common and difference in factors that influence direct and mature students. It is clear from the analysis that, although there are certain factors such as the reputation, alumni and subject-enhancing opportunities that are of no significant difference between direct and mature students, mature students tend to be influence by cost of the education than the direct students. A particular portion of the mature students in the sample are sponsoring their own education. This seems to place affordable fees of their studies to be significant.

\section{Conclusions}

From the study, it emerged that institutional reputation, course entry requirements, subject enhancing employability of subjects and fee affordability played a key role in students enrolment into the Ghanaian languages programme in UEW. In addition, the study revealed that senior high school teachers and alumni play a critical role in the students' choice to study Ghanaian languages in UEW. Furthermore, the study established that combined honour in the study of Ghanaian languages with other subjects such as English language, linguistics etc. tend to attract prospective students. Moreover, employability of the subject was ranked as the second most important factors to students enrol in Ghanaian language programme. Lastly, the study found significant difference between the direct and mature students on course entry requirement, affordable fees and teachers.

In view of these findings, the study recommends that the university authorities, faculty members and administrative staff should ensure the reputation of the university is maintained by offering all stakeholders timely information on programme benefits, course entry requirement and fees schedules, financial aids and fee-payment policies. Also, the university should link up with Ghanaian languages teachers in the country by constantly updating them with information about the programme. Furthermore, the alumni should be offered quality and timely services when needed for them to share their good experiences with prospective students. Again, the university should provide options that allow students to gain a wider variety of academic and other career skills. The university can rebrand its programmes in Ghanaian language to add second subject areas like Journalism, Marketing, Linguistics, Economics, Geography, Special Education, Social Studies etc. The university should provide up to date employment and career information to prospective and current students; they need to negotiate more to the benefits of the programme. Furthermore, more pictures and testimonials might be added that could demonstrate how current students or potential graduates have been able to advance up the corporate ladder. Finally, the university should tailor its messages to prospective students in such a way the different audiences such as direct (traditional) students and mature students concerns are well addressed.

\section{References}

Alonderiene, R., \& Klimavičiene, A. (2013). Insights into Lithuanian students' choice of university and study program in management and economics. Management: journal of contemporary management issues, 18(1), 1-22. Retrieved from https://hrcak.srce.hr/104235

Antti, O. (2016). Factors influencing international degree students' study destination choice - A micro-level research on University of Oulu. Unpublished Master's Thesis, University of 
Oulu.

Beneke, J., \& Human, G. (2010). Student recruitment marketing in South Africa-An exploratory study into the adoption of a relationship orientation. African Journal of Business Management, $4(4), \quad 435 . \quad$ Retrieved from http://www.academicjournals.org/journal/AJBM/article-abstract/053C9E422073

Bick-Har, L. (2012). Why do they want to become teachers? A study on prospective teachers' motivation to teach in Hong Kong. Asia-Pacific Education Researcher, 21(2), 307-314.

Brewer, A., \& Zhao, J. (2010). The impact of a pathway college on reputation and brand awareness for its affiliated university in Sydney. International Journal of Educational Management, 24(1), 34-47.https://doi.org/10.1108/09513541011013033

Chapman, D. W. (1981). A model of student college choice process. Journal of Higher Education, 10(5), 490-505. https://doi.org/10.2307/1981837

Creswell, J. W., Plano Clark, V. L., Gutmann, M. L., \& Hanson, W. E. (2003). Advanced mixed methods research designs. Handbook of mixed methods in social and behavioral research, 209, 240.

Dewitte, E. (2015). It will be of use papa! Indigenous languages in the academy and implications for development. Unpublished Master's Thesis, Kwame Nkrumah University of Science and Technology.

Heslop, L. A., \& Nadeau, J. (2010). Branding MBA programs: The use of target market desired outcomes for effective brand positioning. Journal of Marketing for Higher Education, 20(1), 85-117. https://doi.org/10.1080/08841241003788110

Jackson, G. A. (1982). Public efficiency and private choice in higher education. Educational evaluation and policy analysis, 4(2), 237-247. https://doi.org/10.2307/1164016

James, R., Baldwin, G., \& McInnis, C. (1999). Which University? The factors influencing choices of prospective undergraduates: Evaluation and investigations programme. The Australian Higher Education Division, 12(2), 121-134.

Kerin, R., Harvey, M. \& Crandall, N. F. (1975), Student course selection in a non-required program: An exploratory study. The Journal of Educational Research, 68,175-177. https://doi.org/10.1080/00220671.1975.10884739

Kim, J. K., \& Gasman, M. (2011). In search of a "good college": Decisions and determinations behind Asian American students' college choice. Journal of College Student Development, 52(6), 706- 728. https://doi.org/10.1353/csd.2011.0073

Krejcie, R. V., \& Morgan, D. W. (1970). Determining sample size for research activities. Educational and Psychological Measurement, 30, 607-610. https://doi.org/10.1177/001316447003000308

Kusumawati, A., (2013). A qualitative study of the factors influencing student choice: The case of public university in Indonesia. Journal of Basic and Applied Scientific Research, 3(1), 
314-327.

2018, Vol. 8, No. 2

Kusumawati, A., Yanamandram, V. K., \& Perera, N. (2010).Exploring student choice criteria for selecting an Indonesian public university: A preliminary finding. ANZMAC 2010 Doctoral Colloquium (pp. 1-27). Christchurch, New Zealand: ANZMAC

Lugulu, A. \& Musoga, J. M. (2013). Factors that influence selection of undergraduate degree choices by students in public universities in Kenya: A Case Study of Moi University, Kenya. Retrieved from Http://Hdl.Handle.Net.

Maringe, F. (2006). University and course choice: Implications for positioning, recruitment and marketing. International Journal of Educational Management, 20(6), 466-479. https://doi.org/10.1108/09513540610683711

Ming, J. S. K. (2010). Institutional factors influencing students' college choice decision in Malaysia: A conceptual framework. International Journal of Business and Social Science, $1(3), 55$.

Owoyele, J. W., \& Toyobo, O. M. (2008). Parental will, peer pressure, academic ability and school subjects selection by students in senior secondary schools. The Social Science, 3, 583-586.

Owu-Ewie, C. (2015). Language and literacy in Ghana: Consideration for strengthening language acquisition in Ghanaian schools. Paper presented at the 57th international Conference of Comparative and International Education Society (CIES). New Orleans, USA.

Owu-Ewie, C., \& Edu-Buandoh, D. E. (2014).Living with negative attitudes towards the study of L1 in Ghanaian Senior High Schools (SHS). Ghana Journal of Linguistics 3(2), 1-25. https://doi.org/10.4314/gjl.v3i2.1

Owusu-Agyeman, Y. (2016). Investigating the determinants of adults' participation in higher education. Cogent Education, 1194733. https://doi.org/10.1080/2331186x.2016.1194733

Pampaloni, A. M. (2010). The influence of organizational image on college selection: What students seek in institutions of higher education? Journal of Marketing for Higher Education, 20(1), 19-48. https://doi.org/10.1080/08841241003788037

Poock, M. C., \& Love, P. G. (2001). Factors influencing the program choice of doctoral students

in higher education administration. Naspa Journal, 38(2), 203-223. https://doi.org/10.2202/0027-6014.1136

Reay, D. (2002). It's taking me a long time but I'll get there in the end: Mature students on access courses and higher education choice' British Educational Research Journal, 28, 15 19.

Sabir, R. I., Ahmad, W., Ashraf R. U, \& Ahmad, N. (2013). Factors affecting university and course choice: A Comparism of undergraduate Engineering and Business students in Central 


\section{Macrothink}

International Journal of Learning and Development

Punjab, Pakistan. Journal of Basic and Applied Scientific Research, 3(10), 298-305.

Sierra Sánchez, J. (2012). Factors influencing a student's decision to pursue a communications degree in Spain. Intangible Capital, 8(1), 43-60. https://doi.org/10.3926/ic. 277

University of Education, Winneba, Basic Statistics, 2014. Winneba, Ghana.

University of Education, Winneba, Corporate Strategic Plan, 2003. Winneba, Ghana.

Wagner, K., \& Fard, P. Y. (2009). Factors influencing Malaysian students' intention to study at a higher educational institution. E-Leader Kuala Lumpur.

Wiese, M., Van Heerden, C. H., \& Jordaan, Y. (2010). The role of demographics in students' selection of higher education institutions. Acta Commercii, 10(1), 150-163. https://doi.org/10.4102/ac.v10i1.124

\section{Copyright Disclaimer}

Copyright for this article is retained by the author(s), with first publication rights granted to the journal.

This is an open-access article distributed under the terms and conditions of the Creative Commons Attribution license (http://creativecommons.org/licenses/by/4.0/). 